\title{
Synthesis, Structure, and Antiproliferative Activity of Three Gallium(III) Azole Complexes
}

\author{
Stergios Zanias, ${ }^{1}$ Giannis S. Papaefstathiou, ${ }^{2}$ Catherine P. Raptopoulou, ${ }^{3}$ \\ Konstantinos T. Papazisis, ${ }^{4}$ Vasiliki Vala, ${ }^{4}$ Dimitra Zambouli, ${ }^{4}$ Alexandros H. Kortsaris, ${ }^{4}$ \\ Dimitrios A. Kyriakidis, ${ }^{5,6}$ and Theodoros F. Zafiropoulos ${ }^{1}$
}

${ }^{1}$ Department of Chemistry, University of Patras, 26504 Patras, Greece

${ }^{2}$ Laboratory of Inorganic Chemistry, Department of Chemistry, National and Kapodistrian University of Athens, Panepistimiopolis, 15771 Zografou, Greece

${ }^{3}$ Institute of Materials Science, NCSR "Demokritos”, 15310 Aghia Paraskevi Attikis, Greece

4 "Theagenion" Cancer Hospital, Al. Simeonides str. 2, 54007 Thessaloniki, Greece

${ }^{5}$ Department of Chemistry, Aristotle University of Thessaloniki, 54124 Thessaloniki, Greece

${ }^{6}$ The National Hellenic Research Foundation, 48, Vas. Constantinou Ave, 11635 Athens, Greece

Correspondence should be addressed to Dimitrios A. Kyriakidis, kyr@eie.gr and

Theodoros F. Zafiropoulos, tzafir@chemistry.upatras.gr

Received 25 March 2010; Accepted 1 May 2010

Academic Editor: Spyros Perlepes

Copyright () 2010 Stergios Zanias et al. This is an open access article distributed under the Creative Commons Attribution License, which permits unrestricted use, distribution, and reproduction in any medium, provided the original work is properly cited.

\begin{abstract}
As part of our interest into the bioinorganic chemistry of gallium, gallium(III) complexes of the azole ligands 2,1,3benzothiadiazole (btd), 1,2,3-benzotriazole (btaH), and 1-methyl-4,5-diphenylimidazole (L) have been isolated. Reaction of btaH or btd with $\mathrm{GaBr}_{3}$ or $\mathrm{GaCl}_{3}$ resulted in the mononuclear complexes $\left[\mathrm{GaBr}_{3}(\mathrm{btaH})_{2}\right](\mathbf{1})$ and $\left[\mathrm{GaCl}_{3}(\mathrm{btd})_{2}\right](\mathbf{2})$, respectively, while treatment of $\mathrm{GaCl}_{3}$ with $\mathrm{L}$ resulted in the anionic complex $(\mathrm{LH})_{2}\left[\mathrm{GaCl}_{4}\right](\mathbf{3})$. All three complexes were characterized by singlecrystal X-ray crystallography and IR spectroscopy, while their antiproliferative activities were investigated against a series of human and mouse cancer cell lines.
\end{abstract}

\section{Introduction}

The coordination chemistry of gallium(III) has become an area of increasing research activity due to its relevance with both materials science [1-6] and biomedical developments [7-21]. In the area of materials science, for example, complex $\left[\mathrm{Ga}_{2}(\mathrm{saph})_{2} \mathrm{q}_{2}\right]$, where $\mathrm{saph}^{2-}$ is the Schiff-base ligand bis(salicylidene-o-aminophenolate) $(-2)$ and $\mathrm{q}^{-}$is 8 quinolinate(-1), is a very good candidate as a novel electrontransporting and emitting material for organic light-emitting diodes (OLEDs) [4]. [ $\mathrm{Gaq}_{3}$ ] is also a promising electroluminescence (EL) material, exhibiting higher power efficiency than the aluminum analogue, $\left[\mathrm{Alq}_{3}\right][5,6]$. The biological interest of gallium(III) complexes originates from the incorporation of gallium(III) radionuclides $\left({ }^{67} \mathrm{Ga}^{3+},{ }^{68} \mathrm{Ga}^{3+}\right)$ into diagnostic radiopharmaceuticals [7]. In addition, the gallium salts $\mathrm{GaCl}_{3}$ and $\mathrm{Ga}\left(\mathrm{NO}_{3}\right)_{3}$ as well as few gallium(III) complexes [8-19] have exhibited antitumour activity, while $\mathrm{Ga}\left(\mathrm{NO}_{3}\right)_{3}$ and some $\mathrm{GaCl}_{3} / \mathrm{L}$ complexes $(\mathrm{L}=$ various azoles $)$ showed in vitro anti-HIV (HIV = human immunodeficiency virus) activity [20]. The biological activity of gallium(III) complexes has often been attributed to the fact that gallium(III) is the diamagnetic biological mimic of iron(III) [21]. It is worth mentioning that $\left[\mathrm{Gaq}_{3}\right]$, which is of current interest in materials science $[5,6]$, is also being evaluated in clinical trials, along with other $\mathrm{Ga}$ (III) complexes, such as gallium maltolate [tris(3-hydroxy-2-methyl-4H-pyran-4onato)gallium(III)], for anticancer activity [22-24].

Following our interest in the coordination chemistry of gallium(III) [25-31] which is focused on the synthesis, structural characterization, physical/spectroscopic study and evaluation of the biological (antitumour and antiviral) activity of $\mathrm{Ga}(\mathrm{III})$ complexes with biologically relevant and nonrelevant ligands, we report herein the synthesis, 
structural characterization, and antiproliferative activity of three gallium complexes based on the azole ligands 2,1,3benzothiadiazole (btd), 1,2,3-benzotriazole (btaH), and 1methyl-4,5-diphenylimidazole (L).

\section{Experimental}

2.1. Reagents and Physical Measurements. All manipulations were performed under a dinitrogen atmosphere, using standard inert atmosphere techniques and purified solvents unless otherwise noted. All other chemicals were purchased from commercial sources and used without further purification. L was synthesized as described elsewhere [32]. Microanalyses $(\mathrm{C}, \mathrm{H}$, and $\mathrm{N})$ were performed by the University of Ioannina Microanalytical Laboratory using an EA 1108 Carlo Erba analyzer. IR spectra $\left(4000-450 \mathrm{~cm}^{-1}\right)$ were recorded on a Perkin-Elmer 16 PC spectrometer with samples prepared as $\mathrm{KBr}$ pellets. Far-IR spectra $\left(500-50 \mathrm{~cm}^{-1}\right)$ were recorded on a Bruker IFS 113v FT spectrometer as polyethylene pellets.

\subsection{Compound Preparation}

2.2.1. Preparation of $\left[\mathrm{GaBr}_{3}(\mathrm{btaH})_{2}\right]$ (1). A solution of $\mathrm{GaBr}_{3}(0.3 \mathrm{~g}, 0.9 \mathrm{mmol})$ in $3 \mathrm{ml}$ of toluene/diethyl ether $(80: 20, \mathrm{v} / \mathrm{v})$ was added dropwise to a stirred solution of btaH $(0.3 \mathrm{~g}, 2.5 \mathrm{mmol})$ in toluene $(20 \mathrm{ml})$. The resultant solution was refluxed for about 3 hours and then left undisturbed at room temperature. Upon standing, X-ray quality colorless crystals of 1 formed over a period of 3 days. The crystals were collected by filtration, washed with toluene and dried in vacuum. Yield: $0.31 \mathrm{~g}(63 \%)$; Anal. Calc. for $\mathrm{C}_{12} \mathrm{H}_{10} \mathrm{~N}_{6} \mathrm{Br}_{3} \mathrm{Ga}$ : C, 26.32; H, 1.84; N, 15.34. Found: C, 26.28; H, 1.82; N, $15.33 \%$. Selected IR data $\left(\mathrm{cm}^{-1}\right): 3238 \mathrm{~m}[\nu(\mathrm{N}-\mathrm{H})], 1222 \mathrm{mb}$ $[\nu(\mathrm{N}=\mathrm{N})], 1116 \mathrm{~s}[\nu(\mathrm{N}-\mathrm{N})], 291 \mathrm{~s}[\nu(\mathrm{Ga}-\mathrm{Br})]$, and $224 \mathrm{w}$ $[\nu(\mathrm{Ga}-\mathrm{N})]$.

2.2.2. Preparation of $\left[\mathrm{GaCl}_{3}(b t d)_{2}\right]$ (2). A solution of $\mathrm{GaCl}_{3}$ $(0.25 \mathrm{~g}, 1.40 \mathrm{mmol})$ in $5 \mathrm{ml}$ of toluene/diethyl ether $(80: 20$, $\mathrm{v} / \mathrm{v})$ was added dropwise to a stirred solution of btd $(0.6 \mathrm{~g}$, $4.4 \mathrm{mmol})$ in toluene/diethyl ether $(60: 40, \mathrm{v} / \mathrm{v})(10 \mathrm{ml})$. The resultant solution was refluxed for about 2 hours and then left undisturbed at $-10^{\circ} \mathrm{C}$. Upon standing at low temperature for several days, X-ray quality yellowish crystals of $\mathbf{2}$ formed. The crystals were collected by filtration, washed with diethyl ether and dried in vacuum. Yield: $0.60 \mathrm{~g}(95 \%)$; m.p.: $112^{\circ} \mathrm{C}$. Anal. Calc. for $\mathrm{C}_{12} \mathrm{H}_{8} \mathrm{~N}_{4} \mathrm{~S}_{2} \mathrm{Cl}_{3} \mathrm{Ga}$ : C, 32.14; $\mathrm{H}, 1.80 ; \mathrm{N}, 12.49$. Found: C, 32.13; H, 1.78; N, 12.49\%. Selected IR data $\left(\mathrm{cm}^{-1}\right): 1612 \mathrm{~s}$ and $1528 \mathrm{~s}[\nu(\mathrm{C}=\mathrm{C})], 1482 \mathrm{~s}$ $[\nu(\mathrm{C}=\mathrm{N})], 961 \mathrm{~m}$ and $922 \mathrm{~s}[\nu(\mathrm{S}-\mathrm{N})], 382 \mathrm{~s}[\nu(\mathrm{Ga}-\mathrm{Cl})]$, and $207 \mathrm{w}[\nu(\mathrm{Ga}-\mathrm{N})]$.

2.2.3. Preparation of $(\mathrm{LH})_{2}\left[\mathrm{GaCl}_{4}\right] \mathrm{Cl}$ (3). A solution of $\mathrm{GaCl}_{3}(0.2 \mathrm{~g}, 1.13 \mathrm{mmol})$ in $5 \mathrm{ml}$ of toluene/diethyl ether $(80: 20, \mathrm{v} / \mathrm{v})$ was added dropwise to a stirred mixture of $\mathrm{L}(0.6 \mathrm{~g}, 2.6 \mathrm{mmol})$ in diethyl ether $(1 \mathrm{ml})$. The resultant mixture was stirred until a clear yellowish solution was obtained. Slow evaporation of the resultant solution afforded a microcrystalline solid. The solid was collected by filtration, washed with toluene and diethyl ether, and dried in vacuum. The product was recrystallised three times from toluene to give crystals of $\mathbf{3}$ suitable for X-ray structural analysis. The crystals were collected by filtration, washed with toluene and dried in vacuum. Yield: $0.18 \mathrm{~g}(45 \%)$; Anal. Calc. for $\mathrm{C}_{32} \mathrm{H}_{30} \mathrm{~N}_{4} \mathrm{Cl}_{5} \mathrm{Ga}$ : C, 53.56; H, 4.21; N, 7.81. Found: C, 53.36; $\mathrm{H}, 4.17 ; \mathrm{N}, 7.78 \%$. Selected IR data $\left(\mathrm{cm}^{-1}\right): 3146-2620 \mathrm{sb}$ $[\nu(\mathrm{N}-\mathrm{H})], 1622 \mathrm{~m}[\nu(\mathrm{C}=\mathrm{N})], 1578 \mathrm{w}[\nu(\mathrm{C}=\mathrm{C})]$, and $369 \mathrm{~s}$ $[\nu(\mathrm{Ga}-\mathrm{Cl})]$.

2.3. Single-Crystal X-Ray Crystallography. Crystals of $\mathbf{1}$ and 2 were mounted in air, while crystals of $\mathbf{3}$ were mounted in air and covered with epoxy glue. Diffraction measurements for $\mathbf{1}$ and $\mathbf{2}$ were made on a Crystal Logic Dual Goniometer diffractometer using graphite-monochromated Mo radiation, while those for 3 were made on a P21 Nicolet diffractometer using graphite-monochromated $\mathrm{Cu}$ radiation. Complete crystal data and parameters for data collection and processing are reported in Table 1. Unit cell dimensions were determined and refined by using the angular settings of 25 automatically centred reflections in the ranges $11<2 \theta<23^{\circ}$ for 1 and 2 and $22<2 \theta<54^{\circ}$ for 3. Three standard reflections monitoring every 97 reflections showed less than $3 \%$ variation and no decay. Lorentz, polarization and $\psi$-scan (only for 1) corrections were applied using CRYSTAL LOGIC software. The structures were solved by direct methods using SHELXS-86 [33] and refined by fullmatrix least squares techniques on $F^{2}$ with SHELXL-97 [34]. All hydrogen atoms were located by difference maps and refined isotropically, except those on the methyl groups of 3 which were introduced at calculated positions as riding on bonded atoms. For all the three structures, all nonhydrogen atoms were refined using anisotropic thermal parameters.

\subsection{In Vitro Cytotoxic Activity}

2.4.1. Test Substances. All test substances (complexes 1, 2, and 3) were diluted in methanol at a concentration of $200 \mathrm{mM}$. Final concentration of methanol in culture was always less than $0.5 \%$, a concentration that produced no effects on cell growth and proliferation, as was experimentally confirmed.

2.4.2. Cell Lines. Cell lines used were HeLa [35] (human cervical cancer), OAW-42 [36] (human ovarian cancer), HT29 [37] (human colon cancer), MCF-7 [38] (human breast cancer), T47D [39] (human breast cancer), and L929 (929 is a clone isolated [40] from the parental strain L derived from normal subcutaneous areolar and adipose tissues of a mouse [41]). Cells were grown as monolayer cultures in T-75 flasks (Costar), were subcultured twice a week at $37^{\circ} \mathrm{C}$ in an atmosphere containing $5 \% \mathrm{CO}_{2}$ in air and $100 \%$ relative humidity. Culture medium used was Dulbecco's modified Eagle's medium (DMEM, Gibco Glasgow, UK), supplemented with 10\% Fetal Bovine Serum (FBS, Gibco, Glasgow, UK), $100 \mu \mathrm{g} / \mathrm{ml}$ streptomycin and $100 \mathrm{IU} / \mathrm{ml}$ penicillin. 
2.4.3. Cell Growth and Proliferation Assays. Adherent cells at a logarithmic growth phase were detached by addition of $2-3 \mathrm{ml}$ of a $0.05 \%$ trypsin (Gibco, $1: 250$ ) $-0.02 \%$ EDTA mixture and incubation for $2-5 \mathrm{~min}$ at $37^{\circ} \mathrm{C}$. Cells were plated $(100 \mu \mathrm{l}$ per well) in 96-well flat-bottom microtiter plates (Costar-Corning, Cambridge) at a density of 5,000 (HeLa and L929) or 10,000 (HT-29, OAW-42, MCF-7 and T47D) cells per well. Cells were left for $24 \mathrm{~h}$ at $37^{\circ} \mathrm{C}$ to resume exponential growth. An equal volume $(100 \mu \mathrm{l})$ of either complete culture medium (control wells), or twice the final substance concentration diluted in complete culture medium, was added $24 \mathrm{~h}$ later. Six replicate wells for each concentration were used for the sulforhodamine B (SRB) assay and three replicate wells for the bromodeoxyuridine (BrdU) assay. Background control wells $(n=8)$, containing the same volume of complete culture medium, were included in each experiment. Cell growth or DNA-synthesis was evaluated $48 \mathrm{~h}$ later by means of the SRB or BrdU assays. All experiments were performed at least twice.

2.4.4. SRB Assay. The SRB assay was carried out by a modification [42] of the previously reported method [43]. In brief, culture medium was aspirated prior to fixation using a microplate-multiwash device (Tri-Continent Scientific, Inc. Grass Valley, CA) and $50 \mu \mathrm{l}$ of $10 \%$ cold $\left(4^{\circ} \mathrm{C}\right)$ TCA were gently added to the wells. Microplates were left for $30 \mathrm{~min}$ at $4^{\circ} \mathrm{C}$, washed 5 times with deionized water and left to dry at room temperature for at least $24 \mathrm{hr}$. Subsequently, $70 \mu \mathrm{l} 0.4 \%$ (w/v) sulforhodamine B (Sigma) in 1\% acetic acid solution were added to each well and left at room temperature for 20 min. SRB was removed and the plates were washed 5 times with $1 \%$ acetic acid before air drying. Bound SRB was solubilized with $200 \mu \mathrm{l} 10 \mathrm{mM}$ unbuffered Tris-base solution (E. Merck, Darmstadt, Germany) and plates were left on a plate shaker for at least $10 \mathrm{~min}$. Absorbance was read in a 96well plate reader (Anthos-2001, Anthos labteck instruments, A-5022, Salzburg) at $492 \mathrm{~nm}$ subtracting the background measurement at $620 \mathrm{~nm}$. The test optical density (OD) value was defined as the absorbance of each individual well, minus the blank value ("blank" is the mean optical density of the background control wells, $n=8$ ). Mean values and $\mathrm{CV}$ from six replicate wells were calculated automatically. Results were expressed as the "survival fraction" (sf), derived from the following equation: $\mathrm{sf}=\mathrm{ODx} / \mathrm{ODc}$, (where $\mathrm{ODx}$ and ODc represent the test and the control optical density, resp.).

2.4.5. BrdU Assay. DNA-synthesis was estimated by the BrdU assay [44] using a standard colorimetric ELISA (Boehringer Mannheim). After $47 \mathrm{~h}$ exposure to test substances, cells were incubated at $37^{\circ} \mathrm{C}$ for further 60 min in the presence of $10 \mu \mathrm{M}$ BrdU. Subsequently, cells were fixed with an ethanol-containing fixative, an antiBrdU mouse monoclonal antibody conjugated with peroxidase was added and plates were incubated at $37^{\circ} \mathrm{C}$ for $60 \mathrm{~min}$. After washing, peroxidase substrate (tetramethylbenzidine) was added, the reaction was stopped 10 min later by $1 \mathrm{M} \mathrm{H}_{2} \mathrm{SO}_{4}$ and absorbance was read at
$450 \mathrm{~nm}$ subtracting the background measurement at $620 \mathrm{~nm}$. Results from each triplicate well (ODBrdUx/ODBrdUc) were divided by the results of a parallel experiment estimated with the SRB assay (ODSRBx/ODSRBc) and they were expressed as the "DNA synthesis fraction" (fDNA) (derived from the following equation: fDNA = $(\mathrm{ODBrdUx} \times$ ODSRBc $) /($ ODBrdUc $\times$ ODSRBx $)$, where ODx and ODc represent the test and the control optical density resp.), resulting in an estimation of the DNA synthesis per cell number.

2.4.6. Cell Cycle Analysis by Flow Cytometry. For cell cycle experiments $1.5 \times 10^{6}$ (HeLa and L929) or $2.5 \times 10^{6}$ (HT-29, OAW-42, MCF-7 and T47D) cells were seeded in $75 \mathrm{~cm}^{2}$ flasks and left for $24 \mathrm{~h}$ in incubator to resume exponential growth. Cells were exposed to test substances (at concentrations that produced 50\% inhibition of cell growth-estimated by the SRB assay) and after $48 \mathrm{~h}$ they were harvested (using trypsin/EDTA as above), washed in PBS and counted in a hemocytometer chamber; $3 \times 10^{6}$ cells were resuspended in $125 \mu \mathrm{l}$ cold "Saline GM" (g/L: glucose 1.1; $\mathrm{NaCl}$ 8.0; KCl 0.4; $\mathrm{Na}_{2} \mathrm{HPO}_{4} \cdot 12 \mathrm{H}_{2} \mathrm{O} 0.39 ; \mathrm{KH}_{2} \mathrm{PO}_{4} 0.15$; and $0.5 \mathrm{mM}$ EDTA) followed by the addition of $375 \mu \mathrm{l}$ of $95 \%$ nondenatured, ice-cold ethanol [45]. Cells were kept in $4^{\circ} \mathrm{C}$ for a maximum period of 3 days (short-term storage does not alter results, as was experimentally confirmed) until analysis was performed.

For cell cycle analysis a $10 \%$ of standard chicken erythrocyte nuclei were added as a control. The samples were processed in a DNA-preparation Epics Workstation (Coulter, $\mathrm{El})$. By this method the content of cellular DNA is assessed using Propidium Iodide [46, 47]. To avoid an increased signal by staining artifact on double stranded RNA, cells were digested with DNase-free RNase A [48].

Cellular DNA content was measured using an Epics II flow cytometer (Coulter, El). The fluorescent signals from 10,000-20,000 cells were collected and the result was displayed as a frequency-distribution histogram (DNA histogram). The mean channel, cell count, standard deviation (SD), coefficient of variation (CV), DNA index (DI), and cell cycle distribution were calculated for each sample using the Multicycle Cell Cycle Analysis Software (Phoenix Flow Systems Inc.). Care was taken to exclude any doublets or cell debris noise from the assessment.

\section{Results and Discussion}

3.1. Brief Synthetic Comments. Complexes $\mathbf{1}$ and $\mathbf{2}$ were prepared by the simple reactions of $\mathrm{GaBr}_{3}$ or $\mathrm{GaCl}_{3}$ and btaH or btd in toluene/diethyl ether under nitrogen employing 1:3 molar ratios, respectively. A similar reaction involving $\mathrm{GaCl}_{3}$ and btaH has yielded $\left[\mathrm{GaCl}_{3}(\mathrm{btaH})_{2}\right]$ [25]. An $1: 1$ complex of $\mathrm{GaCl}_{3} / \mathrm{btaH}$ has also been isolated and structurally characterized [25]. An attempt to isolate the $1: 1 \mathrm{GaBr}_{3} / \mathrm{btaH}$ complex was unsuccessful resulting in $\mathbf{1}$ in a lower yield. Complex $\mathbf{2}$ is also the only product resulting from the $\mathrm{GaCl}_{3} / \mathrm{btd}$ reaction mixtures in various molar ratios. Complex $\mathbf{3}$ might be regarded as a product of 
TABLE 1: Crystallographic data for complexes $\left[\mathrm{GaBr}_{3}(\mathrm{btaH})_{2}\right](\mathbf{1}),\left[\mathrm{GaCl}_{3}(\mathrm{btd})_{2}\right](\mathbf{2})$, and $(\mathrm{LH})_{2}\left[\mathrm{GaCl}_{4}\right] \mathrm{Cl}(\mathbf{3})$.

\begin{tabular}{|c|c|c|c|}
\hline & 1 & 2 & 3 \\
\hline Empirical formula & $\mathrm{C}_{12} \mathrm{H}_{10} \mathrm{~N}_{6} \mathrm{Br}_{3} \mathrm{Ga}$ & $\mathrm{C}_{12} \mathrm{H}_{8} \mathrm{~N}_{4} \mathrm{~S}_{2} \mathrm{Cl}_{3} \mathrm{Ga}$ & $\mathrm{C}_{32} \mathrm{H}_{30} \mathrm{~N}_{4} \mathrm{Cl}_{5} \mathrm{Ga}$ \\
\hline Formula weight & 547.68 & 448.42 & 717.60 \\
\hline Crystal colour, habit & Colourless, prism & Colourless, prism & Colourless, prism \\
\hline Crystal dimensions (mm) & $0.15 \times 0.25 \times 0.40$ & $0.20 \times 0.25 \times 0.40$ & $0.15 \times 0.15 \times 0.35$ \\
\hline Crystal system & Monoclinic & Monoclinic & Triclinic \\
\hline Space group & $I 2 / a$ & $C 2 / c$ & $P-1$ \\
\hline$a(\AA)$ & $16.797(10)$ & $12.098(11)$ & $10.2358(10)$ \\
\hline$b(\AA)$ & $7.058(4)$ & $7.525(6)$ & $14.9649(16)$ \\
\hline$c(\AA)$ & $14.276(9)$ & $18.968(16)$ & $12.2350(11)$ \\
\hline$\alpha\left(^{\circ}\right)$ & 90 & 90 & $69.235(4)$ \\
\hline$\beta\left(^{\circ}\right)$ & $106.60(2)$ & $107.65(3)$ & $86.879(3)$ \\
\hline$\gamma\left({ }^{\circ}\right)$ & 90 & 90 & $74.939(4)$ \\
\hline$V\left(\AA^{3}\right)$ & $1621.9(17)$ & $1646(2)$ & $1690.7(3)$ \\
\hline$Z$ & 4 & 4 & 2 \\
\hline$D_{\text {calc }}\left(\mathrm{g} / \mathrm{cm}^{-3}\right)$ & 2.243 & 1.810 & 1.410 \\
\hline$F(000)$ & 1040 & 888 & 732 \\
\hline$\mu\left(\mathrm{mm}^{-1}\right)$ & 9.091 & 2.411 & 4.966 \\
\hline Radiation $(\lambda, \AA)$ & 0.71073 & 0.71073 & 1.54180 \\
\hline Temperature (K) & 298 & 298 & 298 \\
\hline Scan mode & $\theta-2 \theta$ & $\theta-2 \theta$ & $\theta-2 \theta$ \\
\hline Scan speed $\left({ }^{\circ} \min ^{-1}\right)$ & 3.5 & 4.2 & 4.5 \\
\hline Scan range $\left(^{\circ}\right)$ & $2.3+\alpha_{1} \alpha_{2}$ separation & $2.4+\alpha_{1} \alpha_{2}$ separation & $2.25+\alpha_{1} \alpha_{2}$ separation \\
\hline$\theta$ range $\left(^{\circ}\right)$ & $2.53-25.00$ & $2.25-24.99$ & $3.67-61.97$ \\
\hline \multirow{3}{*}{$h k l$ ranges } & 0 to 19 & -14 to 13 & -10 to 9 \\
\hline & 0 to 8 & -8 to 0 & -14 to 17 \\
\hline & -16 to 16 & 0 to 22 & 0 to 14 \\
\hline Reflections collected & 1486 & 1499 & 4586 \\
\hline Independent reflections $\left(R_{\text {int }}\right)$ & $1430(0.0250)$ & $1450(0.0219)$ & $4368(0.0149)$ \\
\hline No of refined parameters & 121 & 118 & 479 \\
\hline Observed reflections $[I>2 \sigma(I)]$ & 1293 & 1341 & 3740 \\
\hline$G O F\left(\right.$ on $\left.F^{2}\right)$ & 1.143 & 1.062 & 1.087 \\
\hline \multirow{2}{*}{ Final $R$ indices ${ }^{\mathrm{a}}[I>2 \sigma(I)]$} & $R_{1}=0.0332$ & $R_{1}=0.0301$ & $R_{1}=0.0345$ \\
\hline & $w R 2=0.0903$ & $w R 2=0.0826$ & $w R 2=0.0830$ \\
\hline \multirow{2}{*}{$\mathrm{R}$ indices ${ }^{\mathrm{a}}$ (all data) } & $R_{1}=0.0375$ & $R_{1}=0.0333$ & $R_{1}=0.0448$ \\
\hline & $w R 2=0.0930$ & $w R 2=0.0852$ & $w R 2=0.1009$ \\
\hline Largest difference peak and hole $\left(\mathrm{e} \AA^{-3}\right)$ & 0.681 and -1.263 & 0.546 and -0.387 & 0.418 and -0.493 \\
\hline
\end{tabular}

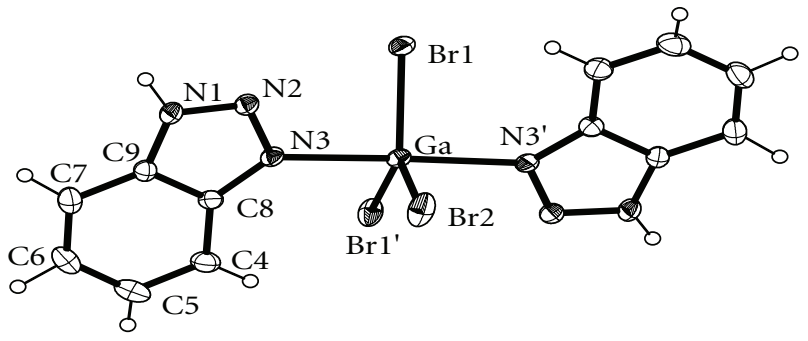

FIgURE 1: A labeled ORTEP plot of $\left[\mathrm{GaBr}_{3}(\mathrm{btaH})_{2}\right]$ (1) showing 30\% probability ellipsoids. 

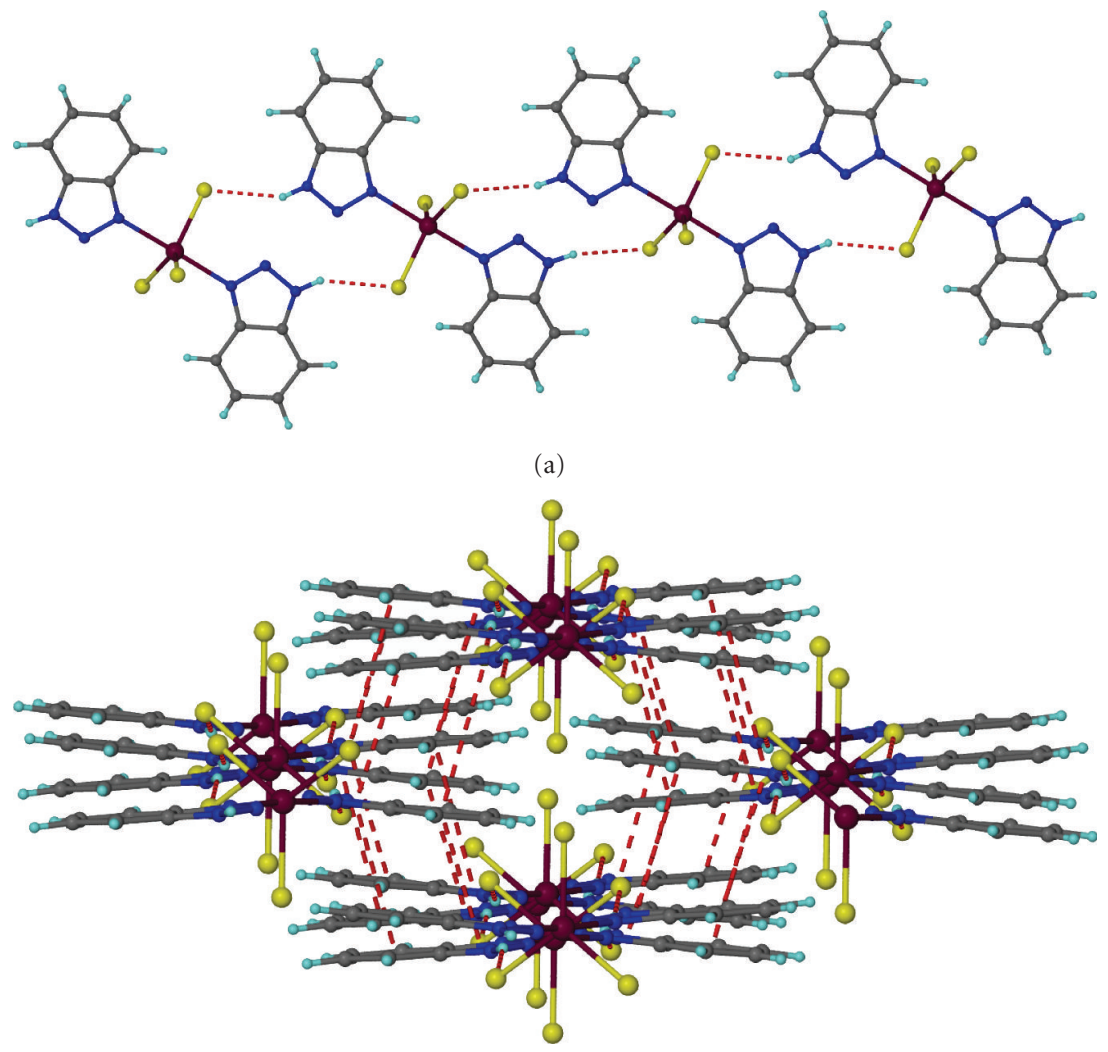

(b)

Figure 2: The hydrogen-bonded tape of $\left[\mathrm{GaBr}_{3}(\mathrm{btaH})_{2}\right]$ (1) running parallel to $a$ axis (a) and the stacking of the tapes (b).

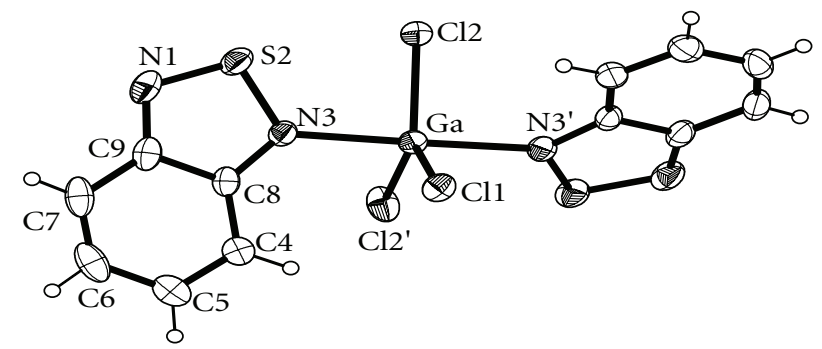

FIGURE 3: A labeled ORTEP plot of $\left[\mathrm{GaCl}_{3}(\mathrm{btd})_{2}\right]$ (2) showing $30 \%$ probability ellipsoids.

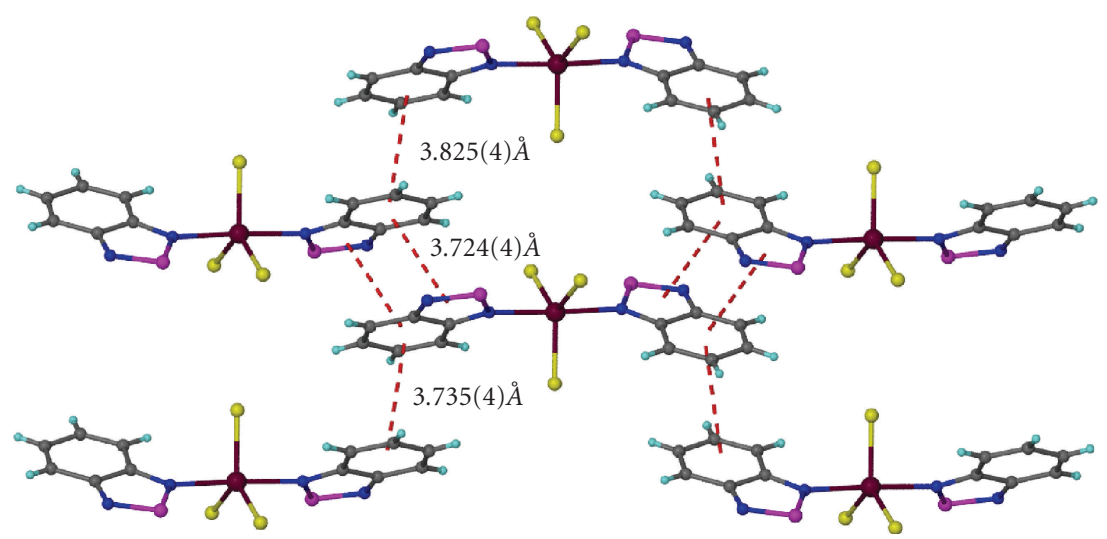

FIgURE 4: The stacking of the $\left[\mathrm{GaCl}_{3}(\mathrm{btd})_{2}\right]$ molecules in 2. 




FIGURE 5: A labeled ORTEP plot of the asymmetric unit of $(\mathrm{LH})_{2}\left[\mathrm{GaCl}_{4}\right] \mathrm{Cl}(3)$, showing $30 \%$ probability ellipsoids.

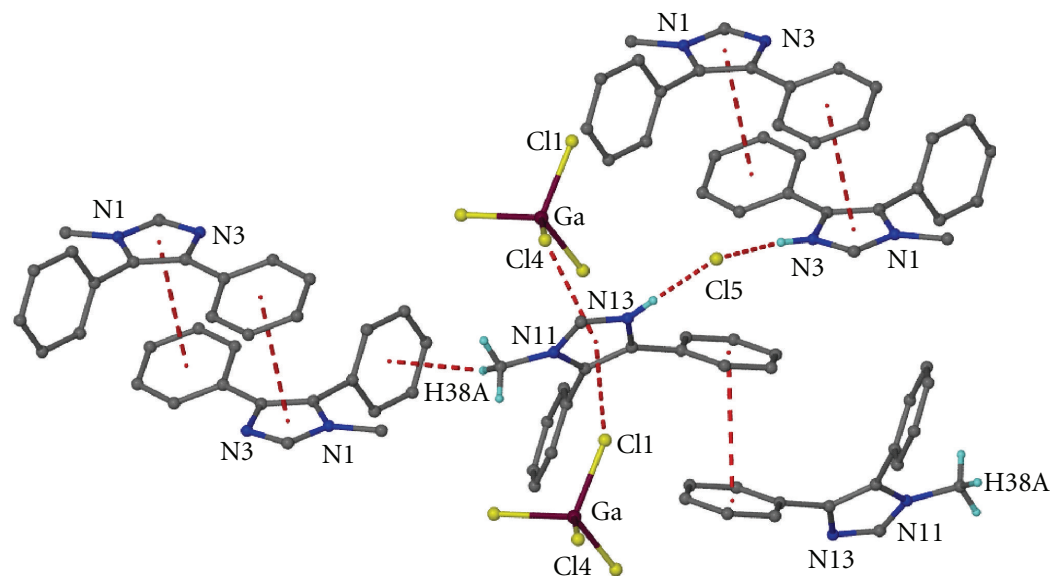

FIGURE 6: The intermixture of the weak interactions between the anions and the cations in 3 . Most of the hydrogen atoms have been omitted for clarity.

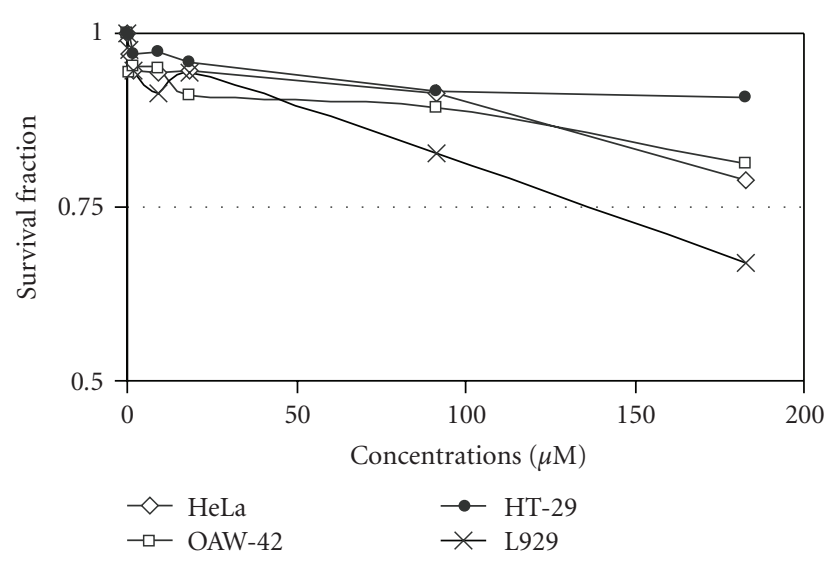

Figure 7: Dose-effect plots of complex 1 against a panel of human and mouse cancer cell lines $24 \mathrm{~h}$ after the administration of the agents. Cytotoxicity was estimated via SRB assay (each point represents a mean of six replicate wells).

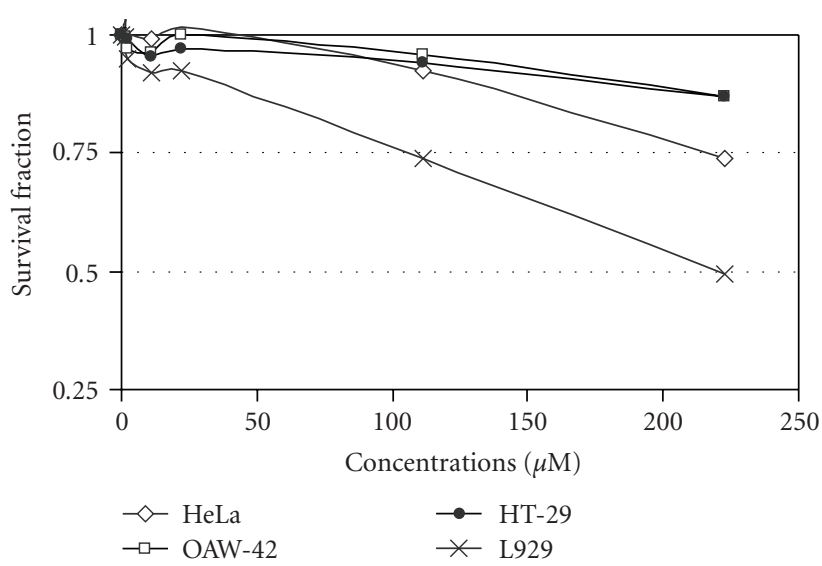

Figure 8: Dose-effect plots of complex 2 against a panel of human and mouse cancer cell lines $24 \mathrm{~h}$ after the administration of the agents. Cytotoxicity was estimated via SRB assay (each point represents a mean of six replicate wells). 
TABle 2: Selected interatomic distances $(\AA ́)$ and angles $\left(^{\circ}\right)$ for complex 1 .

\begin{tabular}{lccc}
\hline $\mathrm{Ga}-\mathrm{N}(3)^{\prime}$ & $2.212(3)$ & $\mathrm{N}(3)-\mathrm{N}(2)$ & $1.314(5)$ \\
$\mathrm{Ga}-\mathrm{N}(3)$ & $2.212(3)$ & $\mathrm{N}(3)-\mathrm{C}(8)$ & $1.378(6)$ \\
$\mathrm{Ga}-\mathrm{Br}(2)$ & $2.3204(17)$ & $\mathrm{N}(1)-\mathrm{N}(2)$ & $1.323(5)$ \\
$\mathrm{Ga}-\mathrm{Br}(1)^{\prime}$ & $2.3436(11)$ & $\mathrm{N}(1)-\mathrm{C}(9)$ & $1.344(6)$ \\
$\mathrm{Ga}-\mathrm{Br}(1)$ & $2.3436(11)$ & $\mathrm{N}(1)-\mathrm{HN} 1$ & $0.89(7)$ \\
$\mathrm{N}(3)^{\prime}-\mathrm{Ga}-\mathrm{N}(3)$ & $176.2(2)$ & $\mathrm{Br}(2)-\mathrm{Ga}-\mathrm{Br}(1)^{\prime}$ & $123.81(3)$ \\
$\mathrm{N}(3)^{\prime}-\mathrm{Ga}-\mathrm{Br}(2)$ & $88.08(10)$ & $\mathrm{N}(3)^{\prime}-\mathrm{Ga}-\mathrm{Br}(1)$ & $90.13(10)$ \\
$\mathrm{N}(3)-\mathrm{Ga}-\mathrm{Br}(2)$ & $88.08(10)$ & $\mathrm{N}(3)-\mathrm{Ga}-\mathrm{Br}(1)$ & $92.01(10)$ \\
$\mathrm{N}(3)^{\prime}-\mathrm{Ga}-\mathrm{Br}(1)^{\prime}$ & $92.01(10)$ & $\mathrm{Br}(2)-\mathrm{Ga}-\mathrm{Br}(1)$ & $123.81(3)$ \\
$\mathrm{N}(3)-\mathrm{Ga}-\mathrm{Br}(1)^{\prime}$ & $90.13(10)$ & $\mathrm{Br}(1)^{\prime}-\mathrm{Ga}-\mathrm{Br}(1)$ & $112.39(6)$ \\
\hline
\end{tabular}

(') Symmetry code: $-x+1 / 2, y,-z+1$.

TABLE 3: Selected interatomic distances $(\AA ́)$ and angles $\left(^{\circ}\right)$ for complex 2.

\begin{tabular}{lccc}
\hline $\mathrm{Ga}-\mathrm{Cl}(1)$ & $2.171(2)$ & $\mathrm{N}(3)-\mathrm{C}(8)$ & $1.357(4)$ \\
$\mathrm{Ga}-\mathrm{Cl}(2)^{\prime}$ & $2.180(1)$ & $\mathrm{N}(3)-\mathrm{S}(2)$ & $1.631(3)$ \\
$\mathrm{Ga}-\mathrm{Cl}(2)$ & $2.180(1)$ & $\mathrm{S}(2)-\mathrm{N}(1)$ & $1.601(3)$ \\
$\mathrm{Ga}-\mathrm{N}(3)$ & $2.201(3)$ & $\mathrm{N}(1)-\mathrm{C}(9)$ & $1.336(5)$ \\
$\mathrm{Ga}-\mathrm{N}(3)^{\prime}$ & $2.201(3)$ & & \\
$\mathrm{Cl}(1)-\mathrm{Ga}-\mathrm{Cl}(2)^{\prime}$ & $120.24(4)$ & $\mathrm{Cl}(2)^{\prime}-\mathrm{Ga}-\mathrm{N}(3)^{\prime}$ & $88.34(9)$ \\
$\mathrm{Cl}(1)-\mathrm{Ga}-\mathrm{Cl}(2)$ & $120.24(4)$ & $\mathrm{Cl}(2)-\mathrm{Ga}-\mathrm{N}(3)^{\prime}$ & $90.45(9)$ \\
$\mathrm{Cl}(2)^{\prime}-\mathrm{Ga}-\mathrm{Cl}(2)$ & $119.52(7)$ & $\mathrm{N}(3)-\mathrm{Ga}-\mathrm{N}(3)^{\prime}$ & $177.58(12)$ \\
$\mathrm{Cl}(1)-\mathrm{Ga}-\mathrm{N}(3)$ & $91.21(6)$ & $\mathrm{C}(8)-\mathrm{N}(3)-\mathrm{S}(2)$ & $107.52(19)$ \\
$\mathrm{Cl}(2)^{\prime}-\mathrm{Ga}-\mathrm{N}(3)$ & $90.45(9)$ & $\mathrm{C}(8)-\mathrm{N}(3)-\mathrm{Ga}$ & $130.00(19)$ \\
$\mathrm{Cl}(2)-\mathrm{Ga}-\mathrm{N}(3)$ & $88.34(9)$ & $\mathrm{S}(2)-\mathrm{N}(3)-\mathrm{Ga}$ & $122.41(14)$ \\
$\mathrm{Cl}(1)-\mathrm{Ga}-\mathrm{N}(3)^{\prime}$ & $91.21(6)$ & $\mathrm{N}(1)-\mathrm{S}(2)-\mathrm{N}(3)$ & $99.20(15)$ \\
\hline
\end{tabular}

(')Symmetry code: $-x+1, y,-z+1 / 2$.

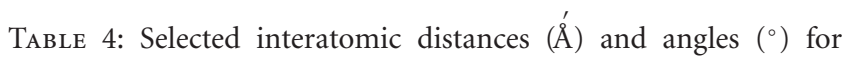
complex 3.

\begin{tabular}{lccc}
\hline $\mathrm{Ga}-\mathrm{Cl}(3)$ & $2.152(1)$ & $\mathrm{C}(2)-\mathrm{N}(3)$ & $1.309(5)$ \\
$\mathrm{Ga}-\mathrm{Cl}(4)$ & $2.166(1)$ & $\mathrm{N}(3)-\mathrm{C}(4)$ & $1.389(4)$ \\
$\mathrm{Ga}-\mathrm{Cl}(1)$ & $2.171(1)$ & $\mathrm{N}(11)-\mathrm{C}(22)$ & $1.320(5)$ \\
$\mathrm{Ga}-\mathrm{Cl}(2)$ & $2.173(1)$ & $\mathrm{N}(11)-\mathrm{C}(25)$ & $1.392(4)$ \\
$\mathrm{N}(1)-\mathrm{C}(2)$ & $1.320(5)$ & $\mathrm{N}(11)-\mathrm{C}(38)$ & $1.463(4)$ \\
$\mathrm{N}(1)-\mathrm{C}(5)$ & $1.393(4)$ & $\mathrm{C}(22)-\mathrm{N}(13)$ & $1.318(5)$ \\
$\mathrm{N}(1)-\mathrm{C}(18)$ & $1.460(4)$ & $\mathrm{N}(13)-\mathrm{C}(24)$ & $1.383(4)$ \\
$\mathrm{Cl}(3)-\mathrm{Ga}-\mathrm{Cl}(4)$ & $110.87(5)$ & $\mathrm{Cl}(3)-\mathrm{Ga}-\mathrm{Cl}(2)$ & $110.55(5)$ \\
$\mathrm{Cl}(3)-\mathrm{Ga}-\mathrm{Cl}(1)$ & $110.17(5)$ & $\mathrm{Cl}(4)-\mathrm{Ga}-\mathrm{Cl}(2)$ & $108.62(5)$ \\
$\mathrm{Cl}(4)-\mathrm{Ga}-\mathrm{Cl}(1)$ & $109.49(5)$ & $\mathrm{Cl}(1)-\mathrm{Ga}-\mathrm{Cl}(2)$ & $107.05(5)$ \\
\hline
\end{tabular}

hydrolysis which is pretty usual in $\mathrm{Ga}$ (III) chemistry in water or water containing solutions [30].

3.2. IR Spectra. The IR spectrum of $\mathbf{1}$ exhibits a medium intensity band at $\sim 3238 \mathrm{~cm}^{-1}$, assignable to $\nu(\mathrm{N}-\mathrm{H})$. The bands at 1222 and $1116 \mathrm{~cm}^{-1}$ are attributed to the $\nu(\mathrm{N}=\mathrm{N})$ and $\nu(\mathrm{N}-\mathrm{N})$ vibrations, respectively, and are shifted to higher wavenumbers with respect to the spectrum of the free
TABle 5: Cell cycle distribution of cells before (control) and after $48 \mathrm{~h}$ exposure to $\mathrm{IC}_{50}$ values of 3 as determined by flow cytometry.

\begin{tabular}{lcccc}
\hline & & G1 $(\%)$ & S (\%) & G2 (\%) \\
\hline HeLa & Control & 62.0 & 26.6 & 11.4 \\
& $\mathbf{3}$ & 57.7 & 35.0 & 7.3 \\
T47D & Control & 57.4 & 28.4 & 14.3 \\
& $\mathbf{3}$ & 58.1 & 34.3 & 7.6 \\
HT29 & Control & 43.5 & 39.4 & 17.1 \\
& $\mathbf{3}$ & 53.2 & 24.6 & 22.2 \\
MCF-7 & Control & 42.0 & 50.4 & 7.6 \\
& $\mathbf{3}$ & 54.1 & 35.4 & 10.5 \\
OAW-42 & Control & 47.8 & 11.3 & 40.9 \\
& $\mathbf{3}$ & 87.2 & 11.8 & 1.0 \\
L929 & Control & 42.0 & 48.0 & 10.0 \\
& $\mathbf{3}$ & 43.0 & 23.6 & 33.4 \\
\hline
\end{tabular}

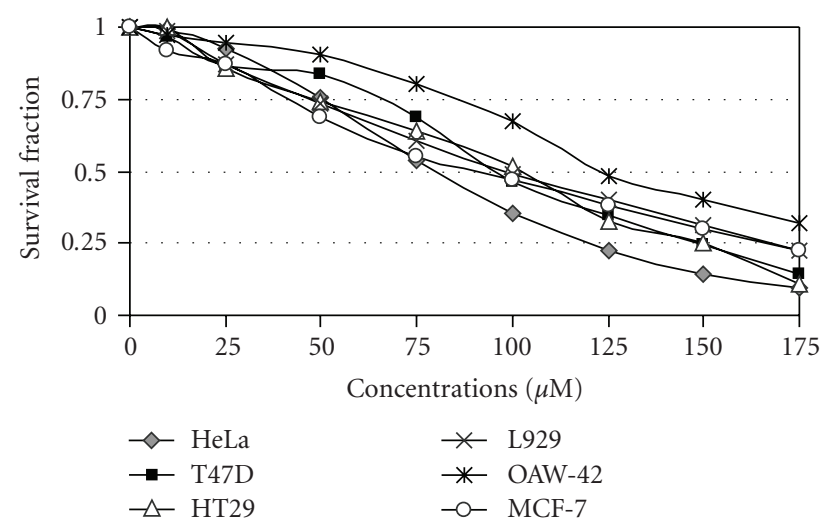

FIGURE 9: Dose-effect plots of complex 3 against a panel of human and mouse cancer cell lines $24 \mathrm{~h}$ after the administration of the agents. Cytotoxicity was estimated via SRB assay (each point represents a mean of six replicate wells).

ligand (1208 versus and $1084 \mathrm{~m}$, resp.). The IR spectrum of 2 exhibits three strong intensity bands at 1612, 1528 and $1482 \mathrm{~cm}^{-1}$ assignable to stretching carbon-carbon and carbon-nitrogen vibrations. These bands are not shifted significantly with respect to the spectrum of the free ligand [ $1608 \mathrm{w}, 1518 \mathrm{~s}$ and $1476 \mathrm{~s}$ ]. The bands at 950 and $916 \mathrm{~cm}^{-1}$ in the spectrum of btd, which are assigned to the $v(\mathrm{~S}-$ $\mathrm{N})$ mode, have been shifted to higher wavenumbers in the spectrum of 2 [961 and $922 \mathrm{~cm}^{-1}$ ]. A set of broad bands in the region of $3146-2620 \mathrm{~cm}^{-1}$ in the spectrum of 3 can be assigned to the $v(\mathrm{~N}-\mathrm{H})$ of the protonated ligand, $\mathrm{LH}^{+}$. The $\nu(\mathrm{C}=\mathrm{N})$ and $\nu(\mathrm{C}=\mathrm{C})$ of the free $\mathrm{L}$ at 1602 and $1575 \mathrm{~cm}^{-1}$ have shifted to 1622 and $1578 \mathrm{~cm}^{-1}$ in the spectrum of 3 due to protonation.

The far-IR spectra of all three complexes are expected to show one $\mathrm{Ga}-\mathrm{X}(\mathrm{X}=\mathrm{Cl}$ or $\mathrm{Br})$ stretching mode [25] and these modes appear at 291s $[\nu(\mathrm{Ga}-\mathrm{Br})$ in 1], 382s $[\nu(\mathrm{Ga}-$ $\mathrm{Cl})$ in 2$]$, and $369 \mathrm{~s}[\nu(\mathrm{Ga}-\mathrm{Cl})$ in 3]. The far-IR spectra of complexes 1 and 2 exhibit one more band at 224 and $207 \mathrm{~cm}^{-1}$, respectively, which are attributed to the $\nu(\mathrm{Ga}-\mathrm{N})$ mode [25]. 


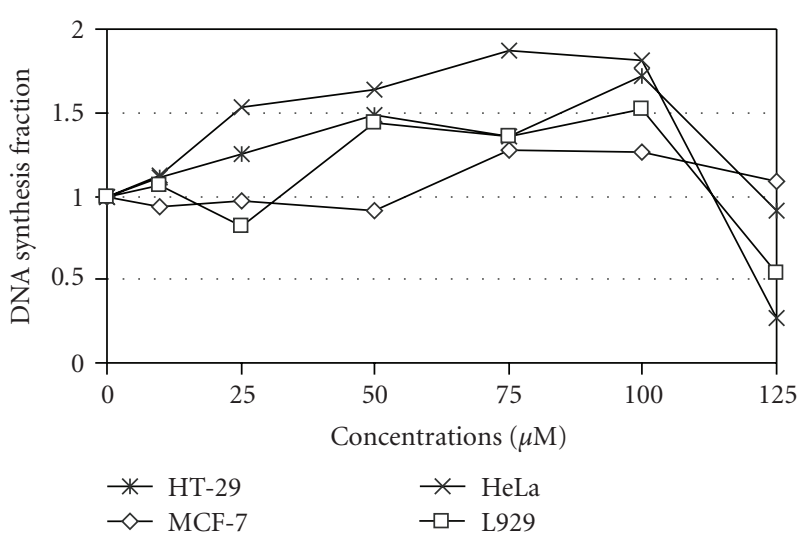

FIGURE 10: DNA synthesis inhibition of human and mouse cancer cell lines $48 \mathrm{~h}$ after the administration of complex 3 .

3.3. Description of Structures. An ORTEP diagram of $\mathbf{1}$ is shown in Figure 1. Selected bond distances and angles are given in Table 2. Complex $\mathbf{1}$ is isostructural with $\left[\mathrm{GaCl}_{3}(\mathrm{btaH})_{2}\right]$ [25]. Its structure consists of the monomeric discrete $\left[\mathrm{GaBr}_{3}(\mathrm{btaH})_{2}\right]$ units. The gallium coordination geometry is trigonalbipyramidal with the bromo ligands defining the equatorial plane. There is a two-fold crystallographic axis along the $\mathrm{Ga}-\mathrm{Br} 2$ bond. The $\mathrm{Ga}-\mathrm{N}$ bond length in complex 1 [2.212(3) $\AA$ ] is longer than that of $\left[\mathrm{GaCl}_{3}(\mathrm{btaH})_{2}\right][2.169(2) \AA]$. The dihedral angle between the best planes of the btaH molecules is $10.90 \AA$ and is larger than that of $\left[\mathrm{GaCl}_{3}(\mathrm{btaH})_{2}\right]\left[7.4^{\circ}\right]$. The N1 proton is hydrogen bonded to atom $\mathrm{Brl}$ of a neighboring molecule $\left[\mathrm{N} 1 \cdots \mathrm{Br} 1^{\prime}(1-x,-y, 1-z) 3.425(4) \AA\right.$, HN1 $\cdots B r 1^{\prime} 2.64(7) \AA$ and N1-HN1 . B Br1' $\left.149(6)^{\circ}\right]$ creating a hydrogen-bonded tape running parallel to the $a$ axis (Figure 2). These tapes are hold together in the crystal lattice through $\pi-\pi$ interactions. Those interactions form between the phenyl groups of the coordinated btaH molecules of neighboring tapes [centroid. ' centroid' $(1-x, 0.5+y$, $1.5-z) 3.658(4)$ and 3.906(4) $\AA$ ] (Figure 2).

Complex 2 crystallizes in the monoclinic space group C2/c. An ORTEP diagram of 2 is shown in Figure 3, while selected bond distances and angles are listed in Table 3. Its structure consists of monomeric discrete $\left[\mathrm{GaCl}_{3}(\mathrm{btd})_{2}\right]$ units. The gallium coordination geometry is again trigonalbipyramidal with the choro ligands defining the equatorial plane. There is a two-fold crystallographic axis along the $\mathrm{Ga}-\mathrm{Cl} 1$ bond. The $\mathrm{Ga}-\mathrm{Cl}$ bond lengths in complex 2 [2.171(2) and 2.180(1) $\AA$ ] compare favourably with those of $\left[\mathrm{GaCl}_{3}(\mathrm{btaH})_{2}\right]$ [2.204(1) and 2.178(2) $\left.\AA\right]$. The Ga-N bond length in complex 2 [2.201(3) $\AA$ ] is longer than that of $\left[\mathrm{GaCl}_{3}(\mathrm{btaH})_{2}\right][2.169(2) \AA]$, but compares well with that of $1[2.212(3) \AA]$. The dihedral angle between the best planes of the btd molecules is $52.51 \AA$ and is much larger than that of 1 and $\left[\mathrm{GaCl}_{3}(\mathrm{btaH})_{2}\right]\left(10.90\right.$ and $7.4^{\circ}$, resp.). There appear to be intermolecular stacking interactions between the nearly parallel btd ligands. Those interactions involve both the thiadiazole and the phenyl groups of the btd ligands as shown in Figure 4.
An ORTEP diagram of the asymmetric unit of 3 is shown in Figure 5. Selected bond distances and angles are listed in Table 4 . The crystal of 3 consists of protonated $\mathrm{LH}^{+}$ligand cations, tetrachlorogallate(III) anions and $\mathrm{Cl}^{-}$ anions. The $\mathrm{Ga}-\mathrm{Cl}$ distances in the tetrahedral $\left[\mathrm{GaCl}_{4}\right]^{-}$ion are in the narrow range 2.152(1)-2.173(1) $\mathrm{A}^{\circ}$ with the $\mathrm{Cl}-$ $\mathrm{Ga}-\mathrm{Cl}$ angles varying from $107.1(1)^{\circ}$ to $110.9(1)^{\circ}$. These values are similar to those observed for other complexes containing the tetrachlorogallate $(-1)$ ion $[13,29]$. The crystal structure of $(\mathrm{LH})_{2}\left[\mathrm{GaCl}_{4}\right] \mathrm{Cl}$ is dominated by an intermixture of $\mathrm{N}-\mathrm{H} \cdots \mathrm{Cl}$ and $\mathrm{C}_{\mathrm{Me}}-\mathrm{H} \cdots \pi$ hydrogen bonds, $\mathrm{Ga}-$ $\mathrm{Cl} \cdots \pi_{\text {azole }}$ and $\pi-\pi$ interactions (Figure 6 ). The organic moieties $\mathrm{LH}^{+}$are connected through $\mathrm{N}-\mathrm{H} \cdot \cdots \mathrm{Cl}$ and $\mathrm{C}-$ $\mathrm{H} \cdots \pi_{\text {phenyl }}$ interactions to form a chain; data are as follows $\mathrm{N} 3 \cdot \cdots \mathrm{Cl}^{\prime}(2-x,-y, 2-z) 3.088(3) \AA$, HN3 $\cdots \mathrm{Cl}^{\prime}$ 2.24(4) $\AA$ and N3-HN3 $\cdots \mathrm{Cl}^{\prime} 160(4)^{\circ}$; N13 $\cdots \mathrm{Cl}^{\prime \prime}(x-$ $1,1+y, z-1) 3.066(4) \AA, H N 13 \cdots \mathrm{Cl}^{\prime \prime} 2.19(5) \AA$ and N13-HN13. . Cl5 $5^{\prime \prime} 177(5)^{\circ}$; C38 . . Centroid' (1 $x,-y, 2-z)$ 3.691(5) $\AA$, H38A . . Centroid' 2.85(1) and C38-H38A $\cdots$ Centroid $^{\prime} 147(1)^{\circ}$. The organic chains are bridged through $\mathrm{Ga}-\mathrm{Cl} \cdots \pi_{\mathrm{azole}}$ interactions to form layers [Cl1 . . Centroid" $(-x, 1-y, 1-z) 3.455(2) \AA$ and Cl4 ‥ Centroid"' $(1-x, 1-y, 1-z) 3.550(2) \AA]$, which are further bridged through $\pi-\pi$ interactions in the third dimension [centroid $\cdots$ centroid' $(1-x,-y, 2-z) 3.778(3)$ and centroid . ' centroid $\left.{ }^{\prime \prime \prime \prime}(-x, 2-y, 1-z) 3.878(3)\right]$.

3.4. Antiproliferative Activity. Complexes 1 (Figure 7) and 2 (Figure 8) had no significant inhibition on cellular proliferation against HeLa, HT29 and OAW-42 cancer cell lines and a small effect against L929 normal fibroblastic cell line. In contrast, complex 3 inhibited cellular growth of all cell lines, with $\mathrm{IC}_{50}$ concentrations varying between 75 and $125 \mu \mathrm{M}$ (Figure 9).

DNA synthesis was not inhibited in HT29, HeLa, MCF-7 or L929 cell lines when they were exposed to 3 at concentrations up to $100 \mu \mathrm{M}$. Higher concentrations exhibited an inhibition of DNA synthesis per cell number only in HeLa and at a lower level in L929 cells (Figure 10).

Treatment with $\mathrm{IC}_{50}$ concentrations of 3 for $48 \mathrm{fh}$ had no effects on cell cycle distribution of HeLa and T47D cells (Table 5). HT29 and MCF-7 were partially arrested at the G1 phase, OAW-42 were arrested at the G1 phase with a percentage of $87.2 \%$ and L929 fibroblasts exhibited a partial G2-phase arrest. However, the overall effect of 3 on cell cycle distribution (except with OAW-42 cells) was not significant, an observation in concert with the results of the BrdU assay, where no inhibition of DNA-synthesis was observed.

\section{Concluding Comments}

In this study, three gallium(III) azole complexes were synthesized and structurally characterized, while their antiproliferative activities were studied. The three different azole ligands were chosen in order to be able to draw structure-properties relations. In two of the complexes (1 and 2 ) the $\mathrm{Ga}$ (III) atom is in a trigonal-bipyramidal coordination environment where the terminal azole ligands occupy the axial positions. 
The third complex (3) consists of $\left[\mathrm{GaCl}_{4}\right]^{-}$anions, chlorine anions and protonated imidazole cations. From the three complexes tested only 3 exhibited a potent anti-proliferative activity against all cell lines tested. The order of cell lines in respect to their sensitivity to $\mathbf{3}$ (at $\mathrm{IC}_{50}$ values) is as follows: HeLa > MCF-7 > T47D > L929 > HT29 > OAW-42. Complex 3 does not inhibit DNA synthesis at concentrations that exert antiproliferative activity $\left(\mathrm{IC}_{50} \mathrm{~s}\right)$ and does not produce major disturbances in cell cycle distribution (with the exception of OAW-42 cells that, notably, are the most resistant to its antiproliferative activity).

\section{Supplementary Information}

CCDC 717554, 717555, and 717553 contain the supplementary crystallographic data for $\mathbf{1}, \mathbf{2}$, and $\mathbf{3}$. These data can be obtained free of charge from the Cambridge Crystallographic Data Center via http://www.ccdc.cam.ac.uk/data_request/cif.

\section{Acknowledgments}

The authors acknowledge the Research Committee of the University of Patras (Grant "K. Caratheodory", 2004-2007) for support of this work. G. S. Papaefstathiou thanks the Special Account for Research Grants (SARG) of the National and Kapodistrian University of Athens for support. This work is dedicated to Professor Nick Hadjiliadis for his retirement.

\section{References}

[1] S. Nakamura and G. Fasol, The BlueLaser Diode, Springer, New York, NY, USA, 1997.

[2] F. A. Ponce and D. P. Bour, "Nitride-based semiconductors for blue and green light-emitting devices," Nature, vol. 386, no. 6623, pp. 351-359, 1997.

[3] Y. Qiu and L. Gao, "Novel synthesis of nanocrystalline gallium nitride powder from gallium(III)-urea complex," Chemistry Letters, vol. 32, no. 8, pp. 774-775, 2003.

[4] J. Qiao, L. D. Wang, L. Duan, Y. Li, D. Q. Zhang, and Y. Qiu, "Synthesis, crystal structure, and luminescent properties of a binuclear gallium complex with mixed ligands," Inorganic Chemistry, vol. 43, no. 16, pp. 5096-5102, 2004.

[5] P. E. Burrows, L. S. Sapochak, D. M. McCarty, S. R. Forrest, and M. E. Thompson, "Metal ion dependent luminescence effects in metal tris-quinolate organic heterojunction light emitting devices," Applied Physics Letters, vol. 64, no. 20, pp. 2718-2720, 1994.

[6] Y. Wang, W. Zhang, Y. Li, L. Ye, and G. Yang, "X-ray crystal structure of gallium tris-(8-hydroxyquinoline): intermolecular $\pi-\pi$ stacking interactions in the solid state," Chemistry of Materials, vol. 11, no. 3, pp. 530-532, 1999.

[7] S. Jurisson, D. Berning, W. Jia, and M. Da, "Coordination compounds in nuclear medicine," Chemical Reviews, vol. 93, no. 3, pp. 1137-1156, 1993.

[8] P. Collery and C. Perchery, in Metal Complexes in Cancer Chemotherapy, B. K. Keppler, Ed., pp. 249-258, VCH, Weinheim, Germany, 1993.

[9] T. Pieper, K. Borsky, and B. K. Keppler, Topics in Biological and Inorganic Chemistry, vol. 1, p. 177, 1999.
[10] M. J. Clarke, F. Zhu, and D. R. Frasca, "Non-platinum chemotherapeutic metallopharmaceuticals," Chemical Reviews, vol. 99, no. 9, pp. 2511-2533, 1999.

[11] M. Thiel, T. Schilling, D. C. Gey, R. Ziegler, P. Collery, and B. K. Keppler, "Relevance of tumor models for anticancer drug development," in Contribution to Oncology, vol. 54, p. 439, 1999.

[12] L. R. Bernstein, T. Tanner, C. Godfrey, and B. Noll, "Chemistry and pharmacokinetics of gallium maltolate, a compound with high oral gallium bioavailability," Metal-Based Drugs, vol. 7, no. 1, pp. 33-47, 2000.

[13] V. B. Arion, M. A. Jakupec, M. Galanski, P. Unfried, and B. K. Keppler, "Synthesis, structure, spectroscopic and in vitro antitumour studies of a novel gallium(III) complex with 2-acetylpyridine 4N-dimethylthiosemicarbazone," Journal of Inorganic Biochemistry, vol. 91, no. 1, pp. 298-305, 2002.

[14] A. V. Rudnev, L. S. Foteeva, C. Kowol et al., "Preclinical characterization of anticancer gallium(III) complexes: solubility, stability, lipophilicity and binding to serum proteins," Journal of Inorganic Biochemistry, vol. 100, no. 11, pp. 1819-1826, 2006.

[15] A. Dobrov, V. B. Arion, N. Kandler et al., "The first metalbased paullone derivative with high antiproliferative activity in vitro," Inorganic Chemistry, vol. 45, no. 5, pp. 1945-1950, 2006.

[16] I. Ott and R. Gust, "Non platinum metal complexes as anticancer drugs," Archiv der Pharmazie, vol. 340, no. 3, pp. 117126, 2007.

[17] C. R. Chitambar, "Gallium compounds as antineoplastic agents," Current Opinion in Oncology, vol. 16, no. 6, pp. 547552, 2004.

[18] P. Collery, B. Keppler, C. Madoulet, and B. Desoize, "Gallium in cancer treatment," Critical Reviews in Oncology/Hematology, vol. 42, no. 3, pp. 283-296, 2002.

[19] M. Frezza, C. N. Verani, D. Chen, and Q. P. Dou, "The therapeutic potential of gallium-based complexes in antitumor drug design," Letters in Drug Design and Discovery, vol. 4, no. 5, pp. 311-317, 2007.

[20] F. Kratz, B. Nuber, J. Weiß, and B. K. Keppler, "Synthesis and characterization of potential antitumour and antiviral gallium(III) complexes of N-heterocycles," Polyhedron, vol. 11, no. 4, pp. 487-498, 1992.

[21] M. Linas, D. M. Wilson, and J. B. Neilands, "Effect of metal binding on the conformation of enterobactin. A proton and carbon-13 nuclear magnetic resonance study," Biochemistry, vol. 12, no. 20, pp. 3836-3843, 1973.

[22] M. A. Jakupec, M. Galanski, V. B. Arion, C. G. Hartinger, and B. K. Keppler, "Antitumour metal compounds: more than theme and variations," Dalton Transactions, no. 2, pp. 183194, 2008.

[23] C. G. Hartinger and B. K. Keppler, "CE in anticancer metallodrug research — an update," Electrophoresis, vol. 28, no. 19, pp. 3436-3446, 2007.

[24] M. A. Jakupec and B. K. Keppler, "Gallium in cancer treatment," Current Topics in Medicinal Chemistry, vol. 4, no. 15, pp. 1575-1583, 2004.

[25] S. Zanias, C. P. Raptopoulou, A. Terzis, and T. F. Zafiropoulos, "Gallium (III) chloride-benzotriazole chemistry: variation of product as a function of metal-to-ligand reaction ratio; preparation, structure and properties of a tetrahedral adduct and the first example of a GaX3L2 trigonal-bipyramidal complex," Inorganic Chemistry Communications, vol. 2, no. 2, pp. $48-51,1999$. 
[26] G. S. Papaefstathiou, S. Manessi, C. P. Raptopoulou, E. J. Behrman, and T. F. Zafiropoulos, "The first metal complex of 5-hydroxyorotic acid: dimethylammonium bis(N,N-dimethylformamide) bis(5-hydroxyorotato(-2))gallate(III)," Inorganic Chemistry Communications, vol. 7, no. 1, pp. 69-72, 2004.

[27] A. Manessi, G. S. Papaefstathiou, C. P. Raptopoulou, A. Terzis, and T. F. Zafiropoulos, "Synthetic analogue approach to metallobleomycins: syntheses, structure and properties of mononuclear and tetranuclear gallium(III) complexes of a ligand that resembles the metal-binding site of bleomycin," Journal of Inorganic Biochemistry, vol. 98, no. 12, pp. 20522062, 2004.

[28] A. Sofetis, G. S. Papaefstathiou, A. Terzis, C. P. Raptopoulou, and T. F. Zafiropoulos, "Preparation, crystal structure and spectroscopic characterization of $[\mathrm{Ga}(\mathrm{OH})$. $\left(\mathrm{SO}_{4}\right)$ (terpy) $\left.\left(\mathrm{H}_{2} \mathrm{O}\right)\right] \cdot \mathrm{H}_{2} \mathrm{O}$ (terpy $=2,2^{\prime}: 6^{\prime}, 2$-Terpyridine): the first characterized gallium(III) sulfato complex," Zeitschrift fur Naturforschung, vol. 59, no. 3, pp. 291-297, 2004.

[29] A. Sofetis, C. P. Raptopoulou, A. Terzis, and T. F. Zafiropoulos, "Structural dependence of the gallium(III) $/ 4,4$ '-dimethyl$2,2^{\prime}$-bipyridine (dmbpy) complexes on the nature of the inorganic anion present: preparation and characterization of $\left[\mathrm{GaCl}_{2}(\mathrm{dmbpy})_{2}\right]\left[\mathrm{GaCl}_{4}\right],\left[\mathrm{GaCl}_{2}(\mathrm{dmbpy})_{2}\right]\left(\mathrm{CIO}_{4}\right)$ and $\left[\mathrm{Ga}(\mathrm{dmpby})_{2}\left(\mathrm{H}_{2} \mathrm{O}\right)_{2}\right]\left(\mathrm{NO}_{3}\right)_{3}$," Inorganica Chimica Acta, vol. 359, no. 10, pp. 3389-3395, 2006.

[30] G. S. Papaefstathiou, A. Manessi, C. P. Raptopoulou, A. Terzis, and T. F. Zafiropoulos, "Methanolysis as a route to gallium(III) clusters: synthesis and structural characterization of a decanuclear molecular wheel," Inorganic Chemistry, vol. 45, no. 22, pp. 8823-8825, 2006.

[31] G. S. Papaefstathiou, A. Sofetis, C. P. Raptopoulou, A. Terzis, G. A. Spyroulias, and T. F. Zafiropoulos, "2,2'-Bipyridine, 1,10phenanthroline and $2,2^{\prime}: 6^{\prime}, 2^{\prime \prime}$-terpyridine in gallium(III) chemistry: complexes containing the $\left\{\mathrm{Ga}_{2}^{\mathrm{III}}(\mu-\mathrm{OH})_{2}\right\}^{4+}$ core," Journal of Molecular Structure, vol. 837, no. 1-3, pp. 5-14, 2007.

[32] J. McMaster, R. L. Beddoes, D. Collison, D. R. Eardley, M. Helliwell, and C. D. Garner, "A bis(diimidazole)copper complex possessing a reversible $\mathrm{Cu}^{\mathrm{II}} / \mathrm{Cu}^{\mathrm{I}}$ couple with a high redox potential," Chemistry European Journal, vol. 2, p. 685, 1996.

[33] G. M. Sheldrick, SHELXS-86: Structure Solving Program, University of Göttingen, Göttingen, Germany, 1986.

[34] G. M. Sheldrick, SHELXL-97: Crystal Structure Refinement Program, University of Göttingen, Göttingen, Germany, 1997.

[35] G. O. Gey, W. D. Coffman, and M. T. Kubicek, "Tissue culture studies of the proliferative capacity of cervical carcinoma and normal epithelium," Cancer Research, vol. 12, p. 513, 1952.

[36] A. P. Wilson, "Characterization of a cell line derived from the ascites of a patient with papillary serous cystadenocarcinoma of the ovary," Journal of the National Cancer Institute, vol. 72, no. 3, pp. 513-521, 1984.

[37] J. Fogh and G. Trempelln, in Human Tumor Cells In Vitro, J. Fogh, Ed., pp. 151-141, Plenum Press, New York, NY, USA, 1975.

[38] H. D. Soule, L. Vasquez, A. Long, S. Albert, and M. Brennan, "A human cell line from a pleural effusion derived from a breast carcinoma," Journal of the National Cancer Institute, vol. 51, no. 5, pp. 1409-1416, 1973.

[39] I. Keydar, L. Chen, S. Karby, et al., "Establishment and characterization of a cell line of human breast carcinoma origin," European Journal of Cancer, vol. 15, pp. 659-670, 1979.
[40] K. K. Sanford, W. R. Earle, and G. D. Likely, "The growth in vitro of single isolated tissue cells," Journal of the National Cancer Institute, vol. 9, no. 3, pp. 229-246, 1984.

[41] W. R. Earle, E. L. Schilling, T. H. Stark, N. P. Straus, M. F. Brown, and E. Shelton, "Production of malignancy in vitro. IV. The mouse fibroblast cultures and changes seen in the living cells," Journal of the National Cancer Institute, vol. 4, pp. 165212, 1943.

[42] P. Skehan, R. Storeng, D. Scudiero et al., "New colorimetric cytotoxicity assay for anticancer-drug screening," Journal of the National Cancer Institute, vol. 82, no. 13, pp. 1107-1112, 1990.

[43] K. T. Papazisis, G. D. Geromichalos, K. A. Dimitriadis, and A. H. Kortsaris, "Optimization of the sulforhodamine B colorimetric assay," Journal of Immunological Methods, vol. 208, no. 2, pp. 151-158, 1997.

[44] J.-P. Magaud, I. Sargent, and D. Y. Mason, "Detection of human white cell proliferative responses by immunoenzymatic measurement of bromodeoxyuridine uptake," Journal of Immunological Methods, vol. 106, no. 1, pp. 95-100, 1988.

[45] H. A. Crissman, in Cell Growth and Apoptosis. A Practical Approach, G. P. Studzinski, Ed., pp. 22-23, Oxford University Press, New York, NY, USA, 1995.

[46] H. A. Crissman and J. A. Steinkamp, "Rapid, simultaneous measurement of DNA, protein, and cell volume in single cells from large mammalian cell populations," Journal of Cell Biology, vol. 59, no. 3, pp. 766-771, 1973.

[47] A. Krishan, "Rapid flow cytofluorometric analysis of mammalian cell cycle by propidium iodide staining," Journal of Cell Biology, vol. 66, no. 1, pp. 188-193, 1975.

[48] M. A. Van Dilla, T. T. Trujillo, P. F. Mullaney, and J. R. Coulter, "Cell microfluorometry: a method for rapid fluorescence measurement," Science, vol. 163, no. 3872, pp. 1213-1214, 1969. 


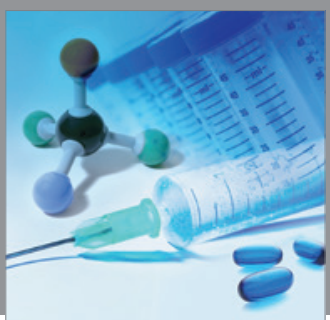

International Journal of

Medicinal Chemistry

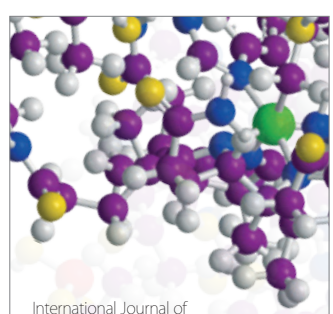

Carbohydrate Chemistry

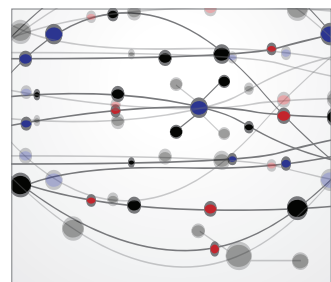

The Scientific World Journal
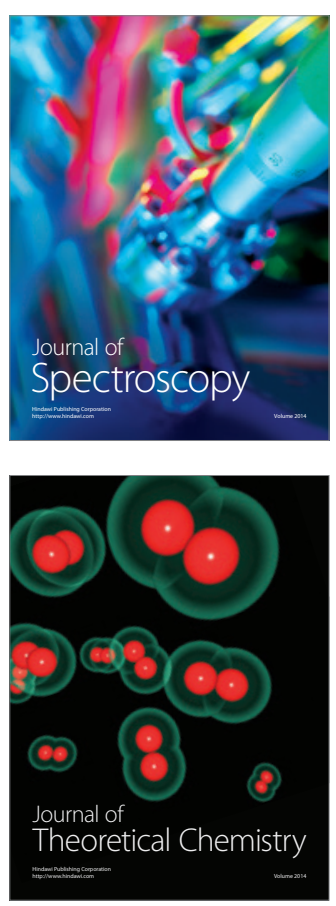
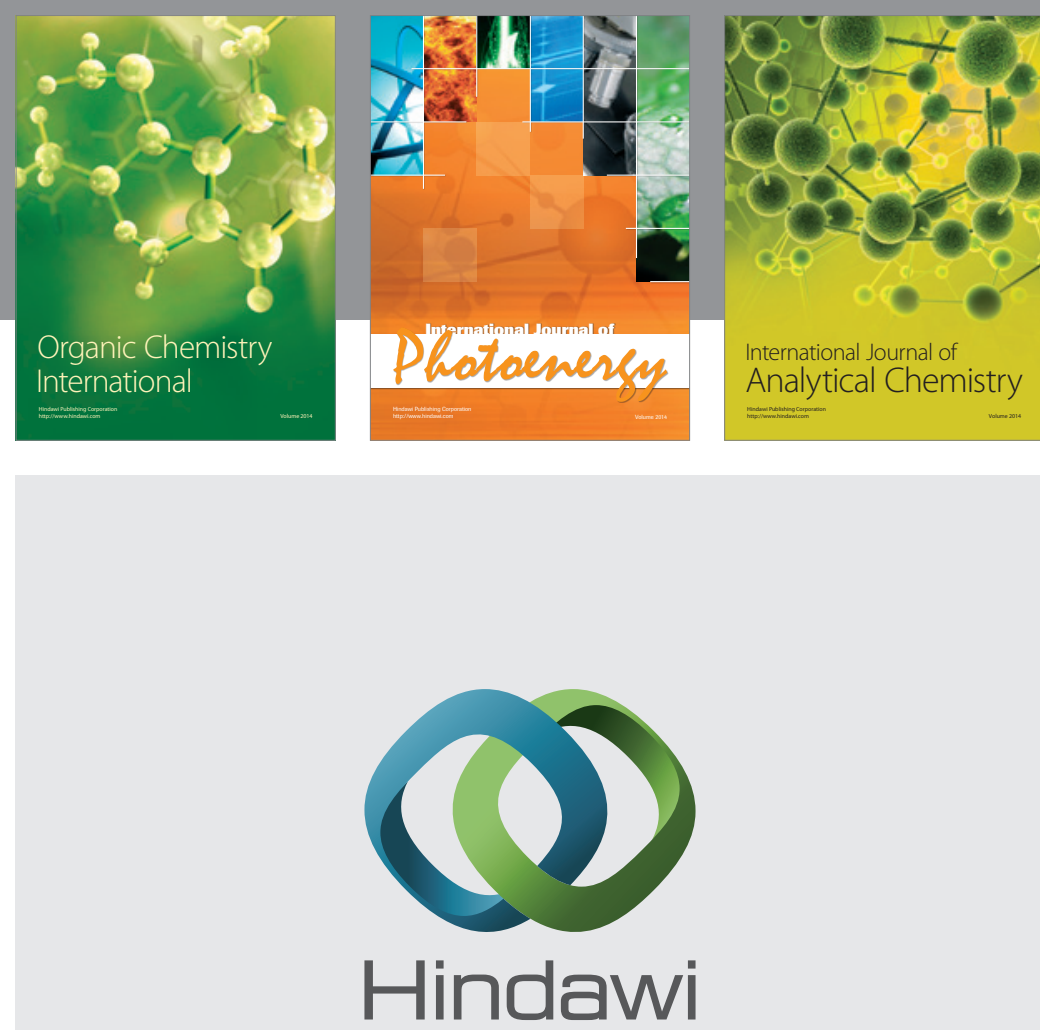

Submit your manuscripts at

http://www.hindawi.com
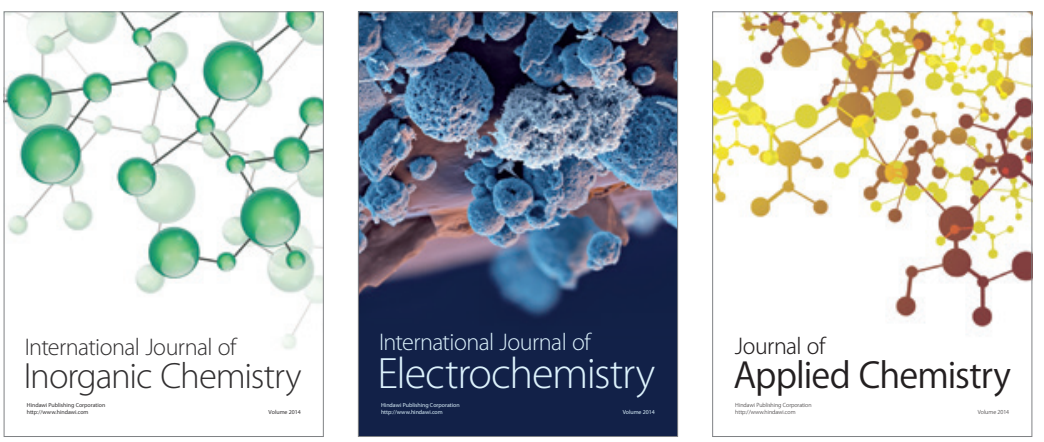

Journal of

Applied Chemistry
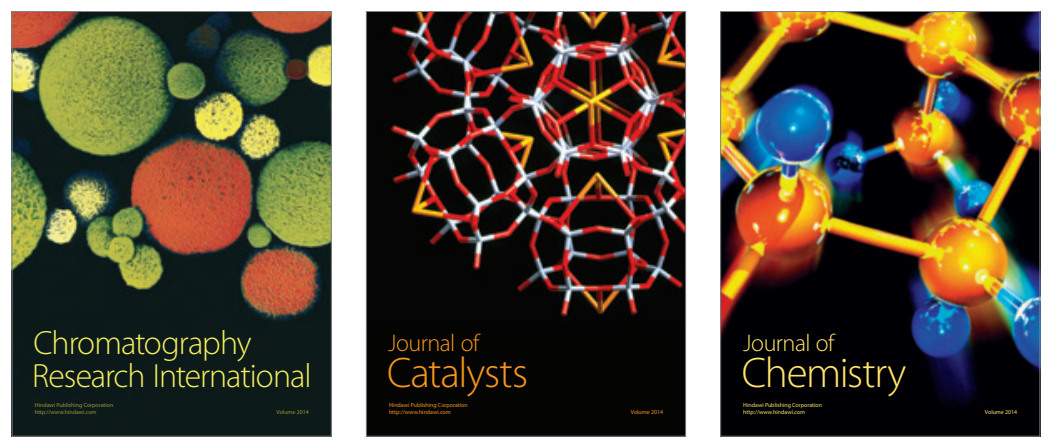
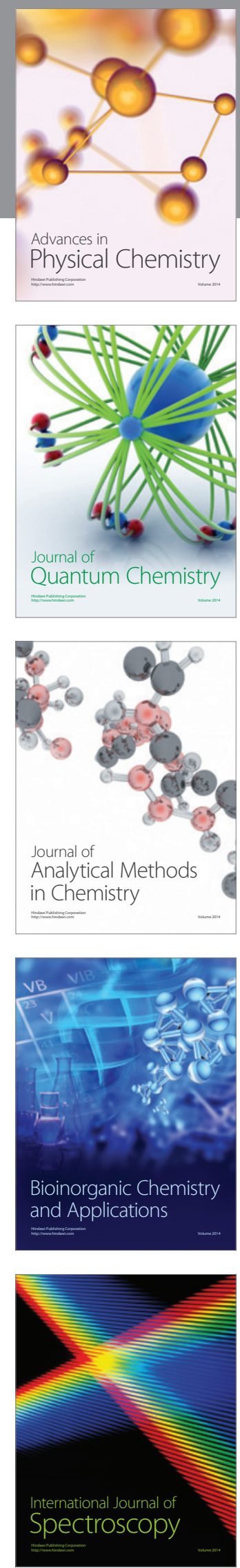